\title{
New species of Eurycletodes Sars, 1909 and Odiliacletodes Soyer, 1964 from the deep Gulf of California (Copepoda, Harpacticoida, Argestidae)
}

\author{
Samuel Gómez' \\ I Instituto de Ciencias del Mar y Limnología, Unidad Académica Mazatlán, Universidad Nacional Autónoma \\ de México; Joel Montes Camarena s/n, Fracc. Playa Sur, Mazatlán, 82040, Sinaloa, México \\ Corresponding author: Samuel Gómez (samuelgomez@ola.icmyl.unam.mx)
}

Academic editor: K.H. George | Received 17 February 2018 | Accepted 7 May 2018 | Published 5 June 2018

http://zoobank.org/5DE332E7-9469-467B-9F04-BE1A59804AAE

Citation: Gómez S (2018) New species of Eurycletodes Sars, 1909 and Odiliacletodes Soyer, 1964 from the deep Gulf of California (Copepoda, Harpacticoida, Argestidae). ZooKeys 764: 1-25. https://doi.org/10.3897/zookeys.764.24511

\begin{abstract}
To date, three species of the family Ancorabolidae, three species of the family Argestidae, and one species of the family Rhizothrichidae are known from the deep sea of the Gulf of California. The descriptions of two new species, Eurycletodes paraephippiger sp. n. and Odiliacletodes secundus sp. n. collected from the Southern Trough of Guaymas Basin at $1440 \mathrm{~m}$ and $1642 \mathrm{~m}$ depths, respectively, are presented herein. The closest relatives of these two species, E. ephippiger Por, 1964 and O. gracilis Soyer, 1964 are known from the Mediterranean, but some relatives have been reported also from the southern Atlantic. Eurycletodes paraephippiger sp. n. is undoubtedly related to E. ephippiger Por, 1964 known from Israel and Banyulssur-Mer (France). These two species can be separated by the armature complement of the basis of the maxillule, by the armature complement of the syncoxa of the maxilliped, and by the relative position of the anal operculum. Odiliacletodes secundus sp. n. showed to be closely related to O. gracilis Soyer, 1964 known from Banyuls-sur-Mer only. The latter two species can be separated by the armature complement of the syncoxa of the maxilliped, by the structure of the antenna, and by the inner armature complement of the third exopodal segment of the fourth swimming leg.
\end{abstract}

\section{Keywords}

Deep Sea, distribution, diversity, taxonomy

Copyright Samuel Gómez. This is an open access article distributed under the terms of the Creative Commons Attribution License (CC BY 4.0), which permits unrestricted use, distribution, and reproduction in any medium, provided the original author and source are credited. 


\section{Introduction}

The family Argestidae is considered a typical deep-sea taxon (Hicks and Coull 1983, Huys and Conroy-Dalton 1997, George 2004). However, some species of several genera of this family have been reported at $200 \mathrm{~m}$ depths or less (Boeck 1872, Sars 1920, Lang 1936, Por 1959, 1967, 1979, Soyer 1966, Menzel et al. 2011). For a more complete list of the bathymetric distribution of the family in general, and of Mesocletodes Sars, 1909 in particular, see George (2004) and Menzel and George (2012). Argestidae are common inhabitants of muddy substrates, are one of the dominant groups of meiobenthic deep-sea harpacticoids (Menzel and George 2009), and some of its genera, e.g., Mesocletodes and Eurycletodes Sars, 1909, are the most abundant in deep-sea samples, accounting for more than $25 \%$ of total abundance of Argestidae (Menzel 2011a). Due to their high abundance and high species richness, this family might play an important ecological role in the benthic realm and is a good subject for phylogenetic, biogeographical, and chorological investigations on deep-sea harpacticoids and meiofauna due to its worldwide distribution (Menzel and George 2009, George 2011). For example, George (2004) hypothesized on how deep-sea argestids may have colonized shallow habitats, and Gómez (2018) reported on some new species of Mesocletodes from the Gulf of California, whose closest relatives have been found in the Angola Basin (Central Atlantic), and are probably present also in the Clarion-Clipperton Fracture Zone (Pacific Ocean) (pers. obs.). Additionally, from Menzel et al. (2011), Menzel and George (2012), and Gómez (2018) it is evident that the same species or closely related species are present in distant localities across vast areas of the world ocean, seemingly "ignoring" geographical barriers. Nevertheless, despite its importance, only few studies are available on the diversity of Argestidae and few of them have tackled the monophyly of the entire family and its constituent genera (e.g., Huys and Conroy-Dalton 1997, George 2004, 2008, 2011, Menzel and George 2009, Corgosinho and Martínez Arbizu 2010, Menzel 2011a, Menzel et al. 2011).

About 225 harpacticoid copepods belonging to an undetermined number of species of 46 genera and 16 families were gathered during examination of deep-sea sediment samples taken during Talud X cruise (February 2007) in the Southern Trough of Guaymas Basin, revealing a high species-richness of benthic harpacticoids (pers. obs.). So far, three species of the family Ancorabolidae, Ancorabolus hendrickxi Gómez \& Conroy-Dalton, 2002, Ceratonotus elongatus Gómez \& Díaz, 2017, and Dendropsyllus californiensis Gómez \& Díaz, 2017, three species of the family Argestidae, Mesocletodes simplex Gómez, 2018, M. brevisetosus Gómez, 2018 and M. unisetosus Gómez, 2018, and one species of the family Rhizothrichidae, Rhizothrix longiseta Gómez, 2018, are known from the deep sea of the Gulf of Califiornia. Here I report on two new species, Eurycletodes paraephippiger sp. n. and Odiliacletodes secundus sp. n. collected from the Southern Trough of Guaymas Basin at $1440 \mathrm{~m}$ and $1642 \mathrm{~m}$ depth, respectively. 


\section{Materials and methods}

Sediment samples for meiofaunal analyses were taken during Talud X cruise (February 2007) in the Southern Trough of Guaymas Basin. Sediment samples were collected at depths ranging from about $379 \mathrm{~m}$ to $1902 \mathrm{~m}$ using a box corer from which triplicate subsamples were taken with $69 \mathrm{~cm}^{2}$ cores of $20 \mathrm{~cm}$ in length. The upper $3 \mathrm{~cm}$ layer of sediment was preserved in $70 \%$ ethanol, sieved through 500 and $38 \mu \mathrm{m}$ sieves to separate macro- and meiofauna, and stained with Rose Bengal. Meiofauna was sorted at a magnification of 40x using an Olympus SZX12 stereomicroscope, and harpacticoid copepods were stored separately in $1 \mathrm{ml}$ vials with 70\% ethanol. Illustrations were made from whole individuals and their dissected parts using a Leica DMLB microscope. The dissected parts were mounted on separate slides using lactophenol as mounting medium. Huys and Boxshall (1991) and Menzel (2011a) were followed for general terminology. Abbreviations used in the text:

acro acrothek;

ae aesthetasc;

EXP exopod;

ENP endopod;

$\operatorname{EXP}(\mathrm{ENP}) \mathbf{1}(2,3) \quad$ first (second, third) exopodal (endopodal) segment;

P1-P6 first to sixth legs;

The type material was deposited in the Copepoda collection of the Instituto de Ciencias del Mar y Limnología, Unidad Académica Mazatlán (ICML-EMUCOP).

\section{Taxonomy}

\section{Family Argestidae Por, 1986}

\section{Genus Eurycletodes Sars, 1909}

Type species. Cletodes laticauda Boeck, 1872 now regarded as a synonym of Eurycletodes (Eurycletodes) laticauda (Boeck, 1872), by original designation.

Other species. Eurycletodes ephippiger Por, 1964, E. paraephippiger sp. n., E. (Eurycletodes) gorbunovi Smirnov, 1946, E. (E.) rectangulatus Lang, 1936, E. (E.) serratus Sars, 1920, E. (Oligocletodes) abyssi Lang, 1936, E. (O.) aculeatus Sars, 1920, E. (O.) arcticus Lang, 1936, E. (O.) denticulatus Por, 1967, E. (O.) diva Menzel, 2011a, E. (O.) echinatus Lang, 1936, E. (O.) hoplurus Smirnov, 1946, E. (O.) irelandica Roe, 1959, E. (O.) latus (T. Scott, 1892), E. (O.) major Sars, 1909, E. (O.) minutus Sars, 1920, E. (O.) monardi Smirnov, 1946, E. (O.) oblongus Sars, 1920, E. (O.) parasimilis Por, 1959, E. (O.) peruanus Becker, 1979, E. (O.) petiti Soyer, 1964, E. (O.) profundus Becker, 1979, E. (O.) quadrispinosa Schriever, 1986, E. (O.) similis (T. Scott, 1895), E. (O.) uniarticulatus Smirnov, 1946, E. (O.) verisimilis Willey, 1935. 


\section{Eurycletodes paraephippiger sp. $\mathbf{n}$.}

http://zoobank.org/F4992154-5397-4E77-9727-CE28797923D8

Material examined. One female holotype (ICML-EMUCOP-020207-01) dissected on eight slides; collected on February 2, 2007.

Type locality. Southern Trough of Guaymas Basin, Gulf of California, Mexico, $27^{\circ} 09^{\prime} 08^{\prime \prime N}, 111^{\circ} 39^{\prime} 57^{\prime \prime W}$, depth $1440 \mathrm{~m}$.

Description of female. Habitus (Figs 1A, 2A) cylindrical, without clear distinction between prosome and urosome. Total body length, $831 \mu \mathrm{m}$, measured from tip of rostrum to posterior margin of caudal rami.

Rostrum well-developed (Fig. 1A, B), fused to cephalothorax, triangular, with pointed tip flanked by apical sensilla on each side.

Cephalothorax and free thoracic somites with reticulated pattern along posterolateral margin, posterior margin coarsely denticulated dorsally and laterally, denticles increasing in size posteriorly (Figs 1A, 2A); with sensilla and tube pores issuing from conspicuous tubercles.

Urosomites with coarsely denticulated posterior margin dorsally and laterally, denticles increasing in size posteriorly (Figs 1A, 2A), much more developed than those of prosomites. Second and third urosomites distinct dorsally and laterally, posterior margin of anterior half of genital-double somite with denticulated posterior margin dorsally (Figs 1A, 2A), fused ventrally forming genital-double somite (Fig. 3A), with reticulated pattern along posterior margin dorsally and laterally, ventral reticulated pattern interrupted medially; posterior margin of second half of genital-double somite and fourth urosomite poorly developed ventrally, of fourth urosomite comparatively coarser and with reticulated pattern as in preceding somite (Fig. 3A); posterior margin of fifth urosomite with well-developed denticles dorsally and ventrally, coarser than in preceding somites, with continuous reticulated pattern along entire posterior margin (Fig. 3A), with dorsal (Fig. 1A) and lateral (Fig. 2A) sensilla and ventral tube-pores (Fig. 3A).

Anal somite nearly as long as three preceding somites combined, almost square from dorsal and lateral view, seemingly without spinular ornamentation dorsally and laterally (Figs 1A, 2A), ventrally cleft medially and with four proximal transverse rows of spinules (Fig. 3A); laterally (Fig. 2A, B) and ventrally (Fig. 3A) with posterior and inner margin, respectively, coarsely denticulated, and with minute spinules close to joint with caudal rami; anal operculum (Fig. 1A, C) coarsely denticulated, associated surface ornamentation seemingly two pores somewhat displaced anteriorly (seemingly without sensilla, probably broken off during dissection).

Caudal rami semi-cylindrical, about 1.6 times as long as broad from dorsal view (Fig. 1C), and about 2 times as long as broad from ventral view (Fig. 3A, B); ventrally with some minute spinules and one tube pore subdistally (the latter arrowed in Figs 1C, 2B, 3B); with seven setae as follows: seta I small, ventral and anterior to seta II, the latter about 3 times as long as the former; seta III arising from small protrusion, situated ventrally close to inner margin; setae IV and V longest; seta VI arising at inner distal corner, as long as seta I; dorsal seta VII tri-articulated, issuing from median dorsal process. 


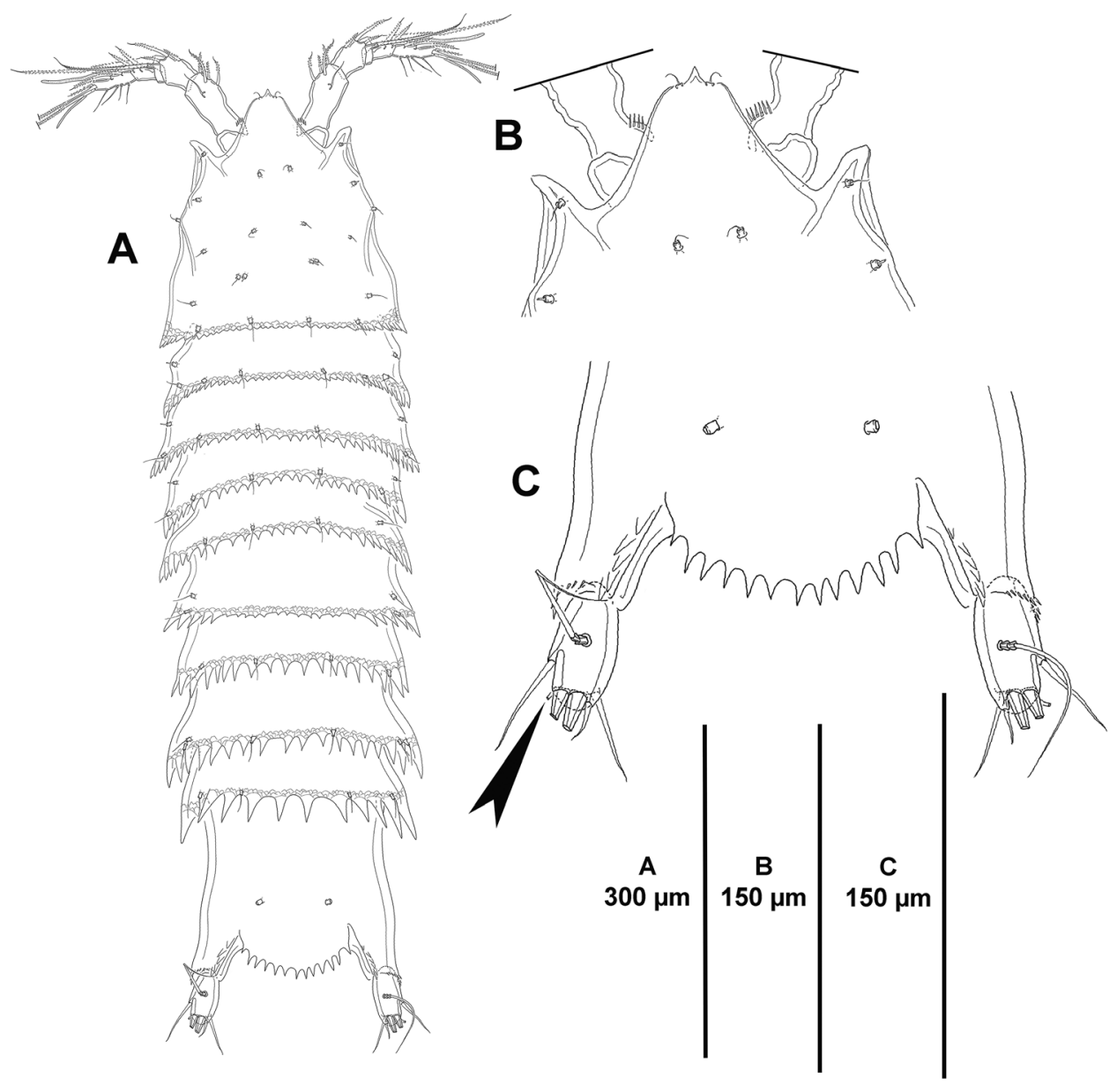

Figure I. Eurycletodes paraephippiger sp. n., female holotype. A habitus, dorsal B anterior part of the cephalothorax and rostrum, dorsal C posterior part of anal somite and caudal rami, dorsal.

Antennule (Fig. 4A). Hexa-segmented; first segment small; second segment longest; surface of segments smooth except for spinular row on first segment; fifth segment with two well-developed bipinnate setae and a modified small element (see insert in Fig. 4A); last segment with five bi-articulated setae, one subapical well-developed seta, and acrothek, the latter consisting of one aesthetasc and two setae fused basally. Armature formula as follows: $1(0) ; 2(7) ; 3(4+[1+\mathrm{ae}]) ; 4(1) ; 5(3) ; 6(8+[\mathrm{acro}])$.

Antenna (Fig. 4B). Allobasis ornamented with inner spinules as shown; without abexopodal seta. Exopod represented by single seta. Free endopodal segment with longitudinal spinular row along inner proximal margin, and with some subdistal spinules; with two lateral, bare, inner spines (proximal one clearly longer), and five distal elements (two spines, and two geniculate elements, of which outermost fused to one small seta basally). 


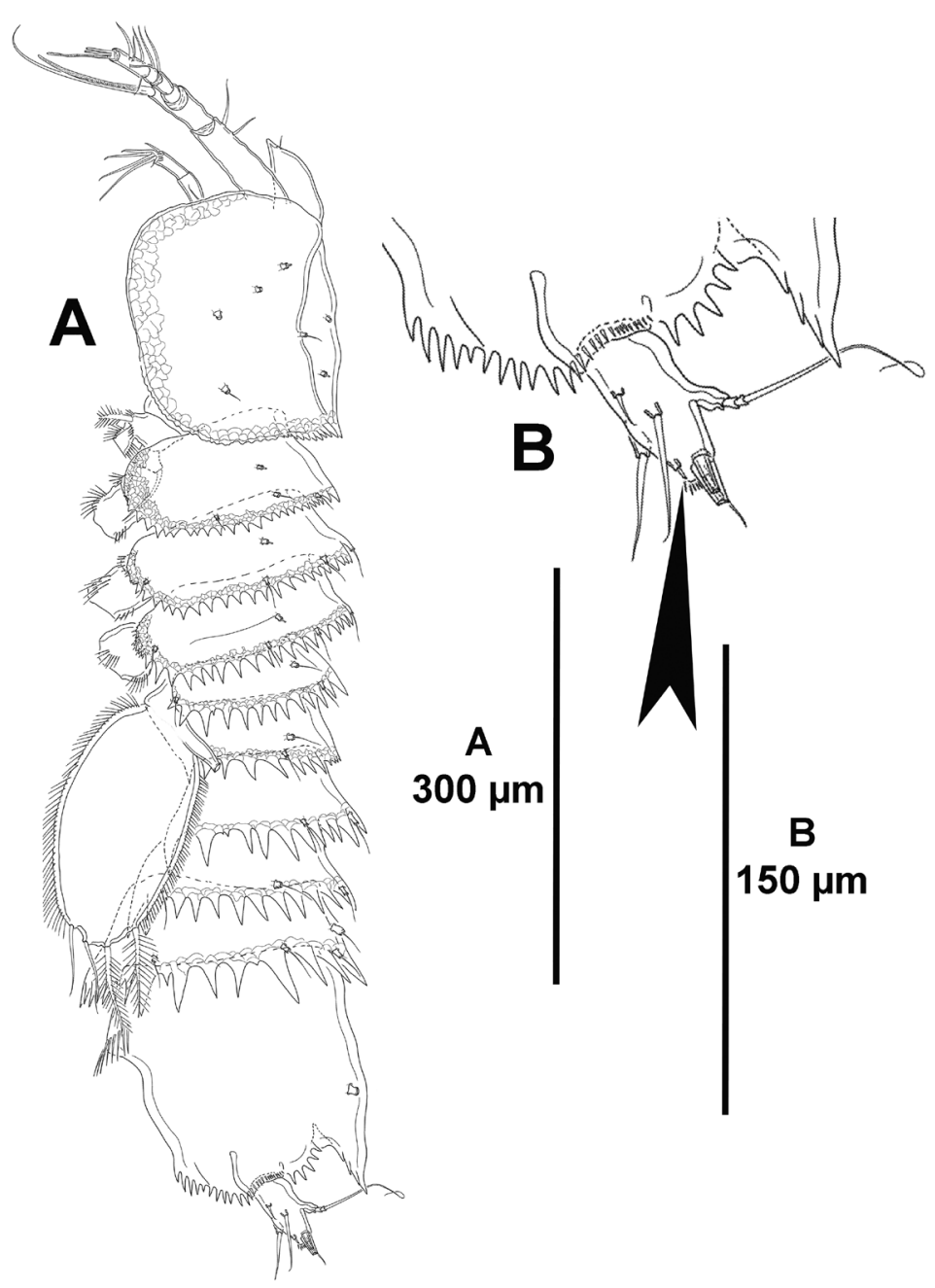

Figure 2. Eurycletodes paraephippiger sp. n., female holotype. A habitus, lateral B posterior part of anal somite and left caudal ramus, lateral.

Mandible (Fig. 5A). Coxa with some proximal spinules. Gnathobase formed by four tooth-like projections, and with a lateral small seta. Palp bi-segmented; first (basal) segment with spinules as shown, without basal seta, with one outer (exopodal) seta; second (endopodal) segment without surface ornamentation, with four bare setae, two of which fused basally.

Maxillule (Fig. 5B). Praecoxa with some proximal spinules; arthrite with six distal spines, one lateral and two surface setae. Coxal endite with three setae, one of which very strong and pinnate. Basis with some spinules, armed with one bare and one pinnate seta. Without endopod. Exopod represented by one pinnate seta.

Maxilla (Fig. 5C). Syncoxa with outer spinules, with two endites; proximal endite small, with one slender seta; distal endite with two slender setae and one strong spi- 


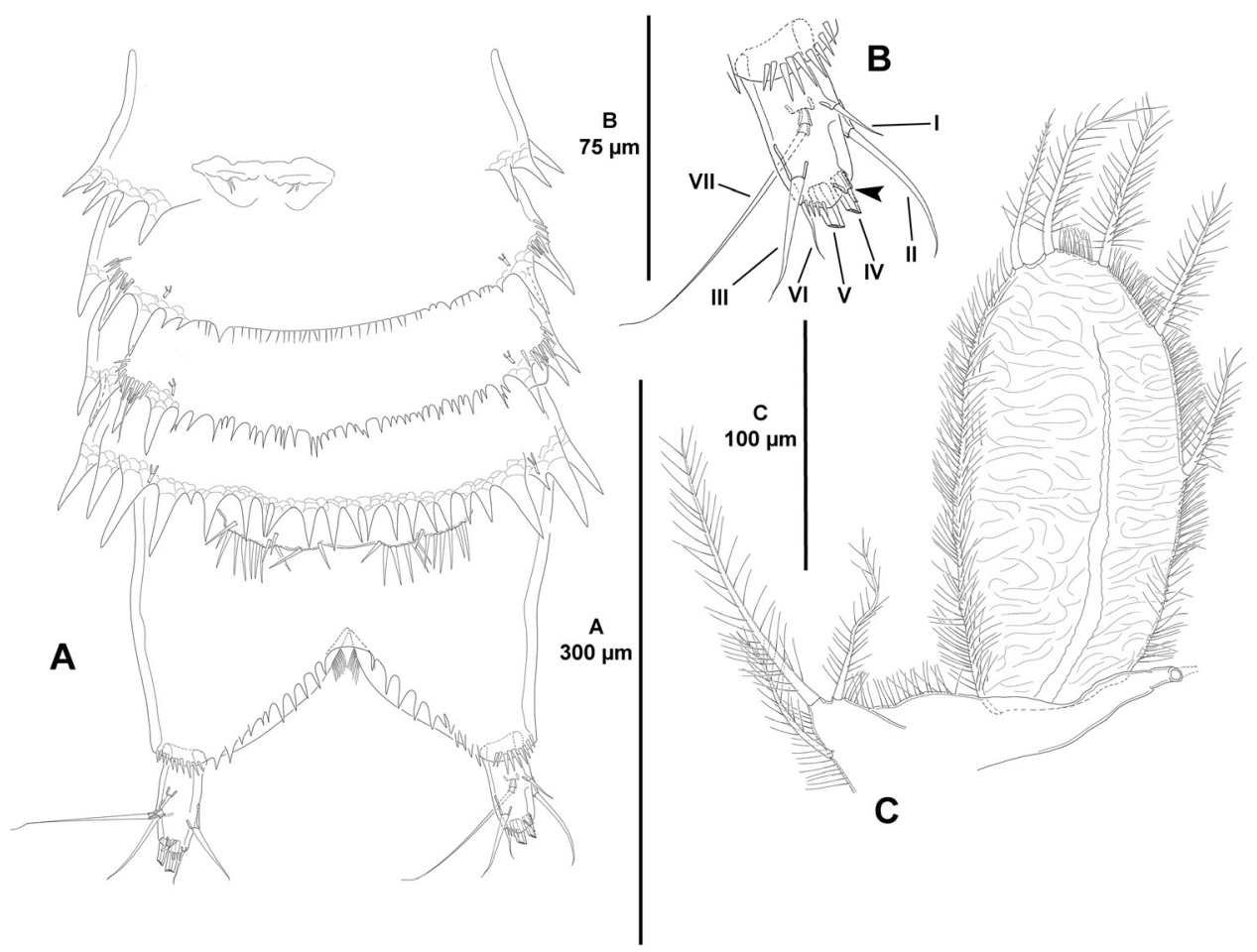

Figure 3. Eurycletodes paraephippiger sp. n., female holotype. A urosome, ventral (P5-bearing somite omitted) B caudal ramus, ventral (tube pore arrowed) C P5, anterior.

nulose element. Allobasis with some slender spinules, drawn out into strong pinnate claw, with two slender bare setae, one of which small and issuing from claw proximally, and a strong spinulose spine. Endopod uni-segmented, small, with two pinnate seta.

Maxilliped (Fig. 5D). Subchelate. Syncoxa with inner and outer tuft of slender spinules, with two setae. Basis with longitudinal outer spinules, unarmed. Endopod uni-segmented, fused to long, slender, pinnate claw.

P1 (Fig. 6A). Coxa with spinules as shown. Basis with outer and inner seta, the former stronger, with spinules at base of outer seta and at base of endopod. Exopod and endopod subequal in length. Exopod tri-segmented; segments with outer and apical spinules as shown; first and third segment subequal in length, second segment half as long as first segment; first segment without, second segment with one inner seta, third segment with two apical and three outer setae/spines. Endopod bi-segmented; first segment about 1.5 times as long as wide, with longitudinal row of outer, fine spinules, with one inner seta; second segment elongate, with one inner, two apical and one outer element, of which outer a spine.

P2-P4 (Figs 6B, 7A, B). Praecoxa presumably as in P2, with row of distal spinules. Coxa presumably as in $\mathrm{P} 2$ and $\mathrm{P} 3$, with one median, proximal row of minute spinules on anterior face, and long spinules close to outer margin on anterior and posterior face. Basis more or less triangular in shape with slender, long spinules along inner margin, with small 


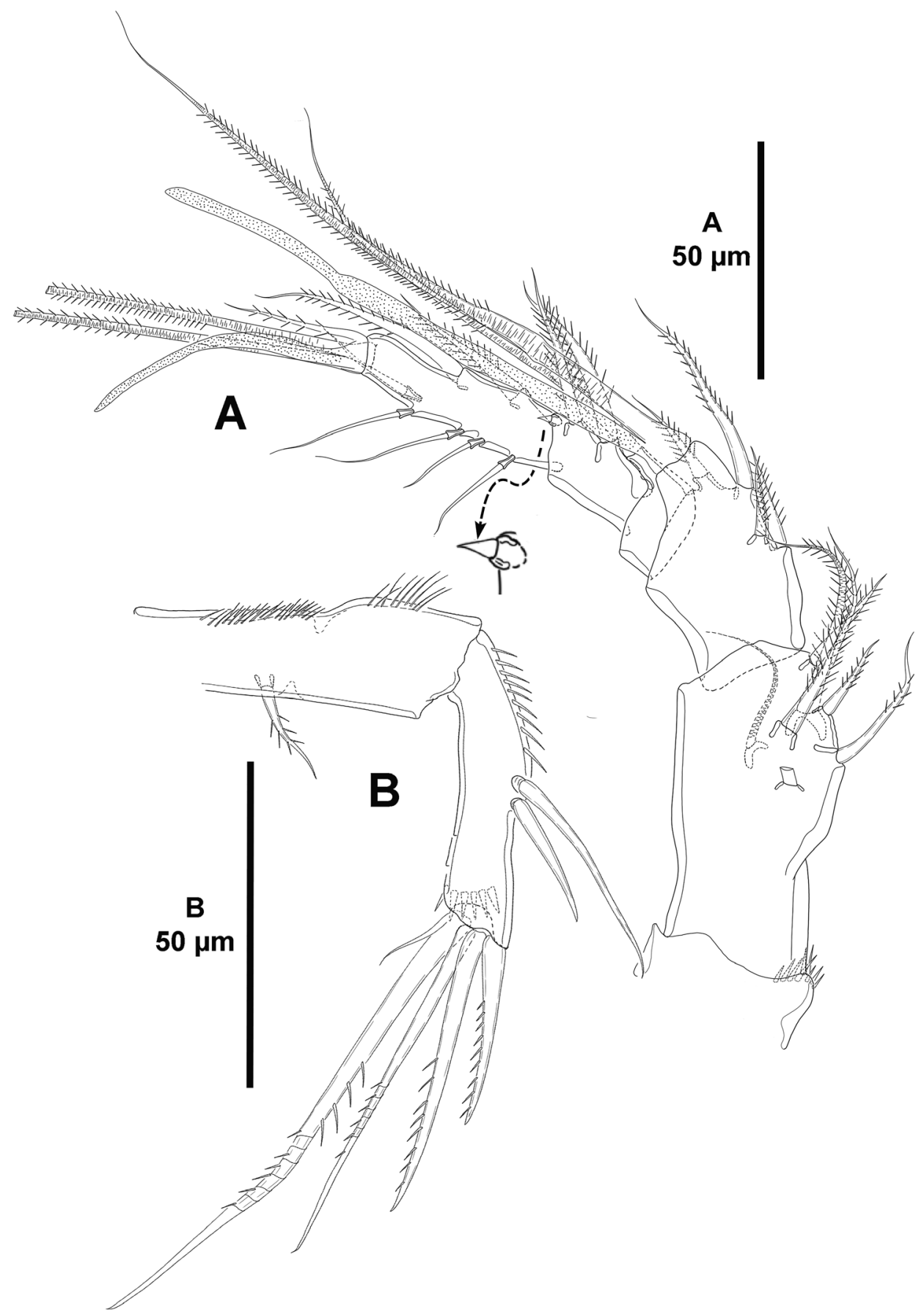

Figure 4. Eurycletodes paraephippiger sp. n., female holotype. A antennule B antenna. 


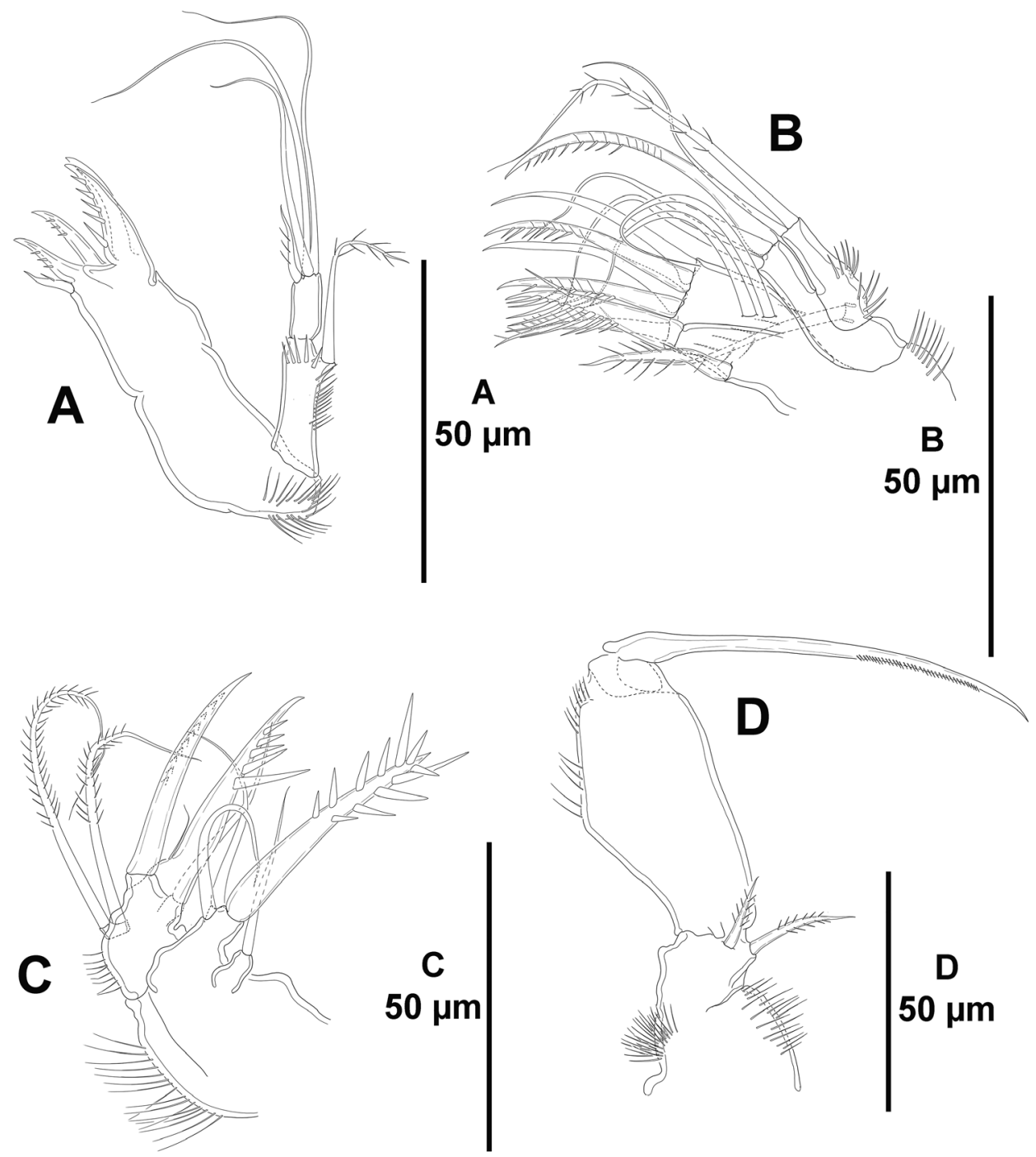

Figure 5. Eurycletodes paraephippiger sp. n., female holotype. A mandible B maxillule $\mathbf{C}$ maxilla D maxilliped.

spinules at base of endopod, of $\mathrm{P} 2$ without, of $\mathrm{P} 3$ and $\mathrm{P} 4$ with spinules at base of outer element; outer element spine-like in P2, a long, well-developed seta in P3 and P4. Exopod tri-segmented; first and third segment elongate, third segment slightly longer; second segment small, as long as broad; segments with inner slender, and outer strong spinules as shown; first segment with irregular outer margin; first and second segments with one inner seta; third segment of $\mathrm{P} 2$ and $\mathrm{P} 3$ with two inner well-developed setae, two apical setae and three outer spines, of $\mathrm{P} 4$ with two inner elements, of which proximal reduced and spine-like, two apical setae and three outer spines. Endopod bi-segmented; of P2 and P3 reaching insertion of proximal inner seta of EXP3, of $\mathrm{P} 4$ barely beyond apical margin of 


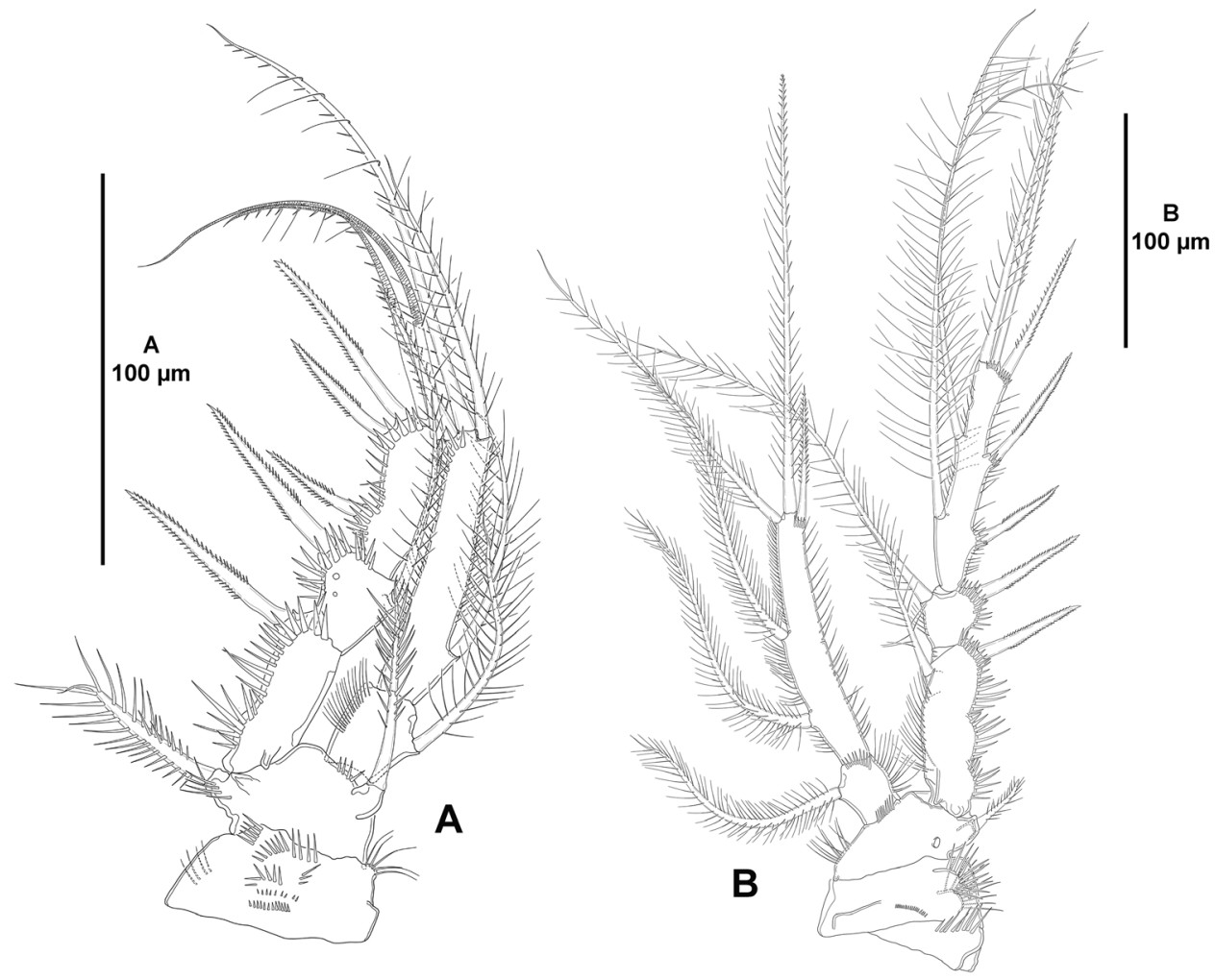

Figure 6. Eurycletodes paraephippiger sp. n., female holotype. A P1, anterior B P2, anterior.

EXP2; first segment small, 1.5 times as long as wide, with one inner seta; second segment elongate, of $\mathrm{P} 2$ and $\mathrm{P} 3$ with five (two inner and two apical setae, and one outer spine), of P4 with four setae/spines (one inner and two apical setae, and one outer spine.

Armature formula of P1-P4 as follows:

\begin{tabular}{c|c|c|c|c}
\hline & P1 & P2 & P3 & P4 \\
\hline EXP & I-0;I-1;III,2,0 & I-1;I-1;III,2,2 & I-1;I-1;III,2,2 & I-1;I-1;III,2,1I \\
\hline ENP & $0-1 ; \mathrm{I}, 2,1$ & $0-1 ; \mathrm{I}, 2,2$ & $0-1 ; \mathrm{I}, 2,2$ & $0-1 ; \mathrm{I}, 2,1$ \\
\hline
\end{tabular}

P5 (Fig. 3C). Baseoendopod and exopod distinct. Baseoendopod with outer basal seta on short setophore, endopodal lobe with three setae, of which median longest. Exopod large, foliose, ovate, with reticulated surface, about 2 times as long as wide, with five setae, with slender spinules along inner and outer margin, and between setae, except between inner most and adjacent element.

P6 (Fig. 3A). Very reduced, each leg represented by two small setae; genital field located medially, with one aperture.

Male unknown.

Etymology. The specific epithet and the Latin suffix pär, similar, refers to the resemblance between the new species and E. ephippiger Por, 1964. Gender masculine. 

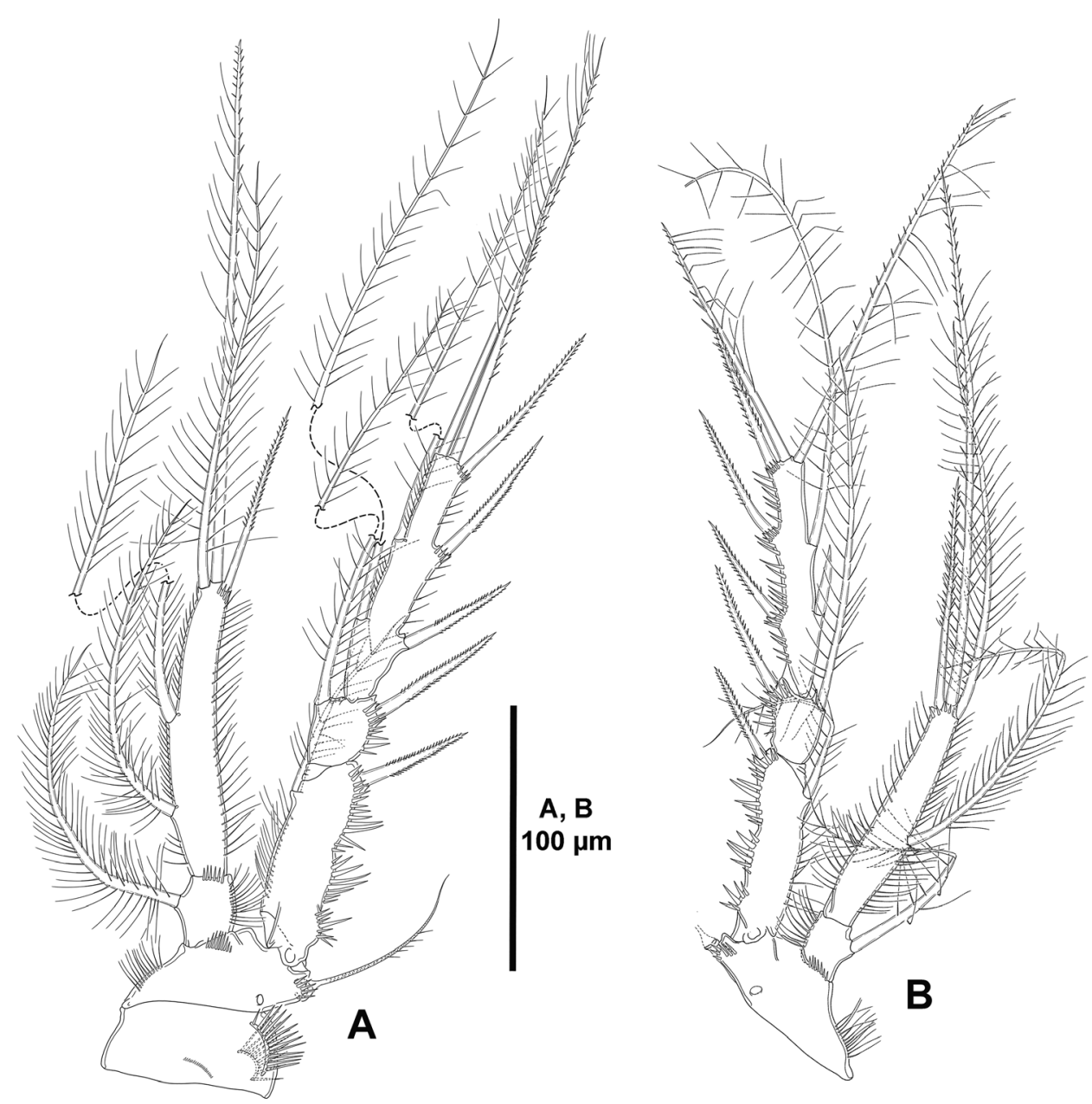

Figure 7. Eurycletodes paraephippiger sp. n., female holotype. A P3, anterior B P4 anterior.

\section{Genus Odiliacletodes Soyer, 1964}

Type species. Odiliacletodes gracilis Soyer, 1964, by monotypy.

Other species. Odiliacletodes secundus sp. n.

\section{Odiliacletodes secundus sp. n.}

http://zoobank.org/888683DE-2B29-41AC-AB0A-080E129471CD

Material examined. One female holotype (ICML-EMUCOP-130207-02) dissected on seven slides; collected on February 13, 2007.

Type locality. Southern Trough of Guaymas Basin, Gulf of California, Mexico, $27^{\circ} 07^{\prime} \mathrm{N}, 110^{\circ} 53.4^{\prime} \mathrm{W}$, depth $1642 \mathrm{~m}$. 


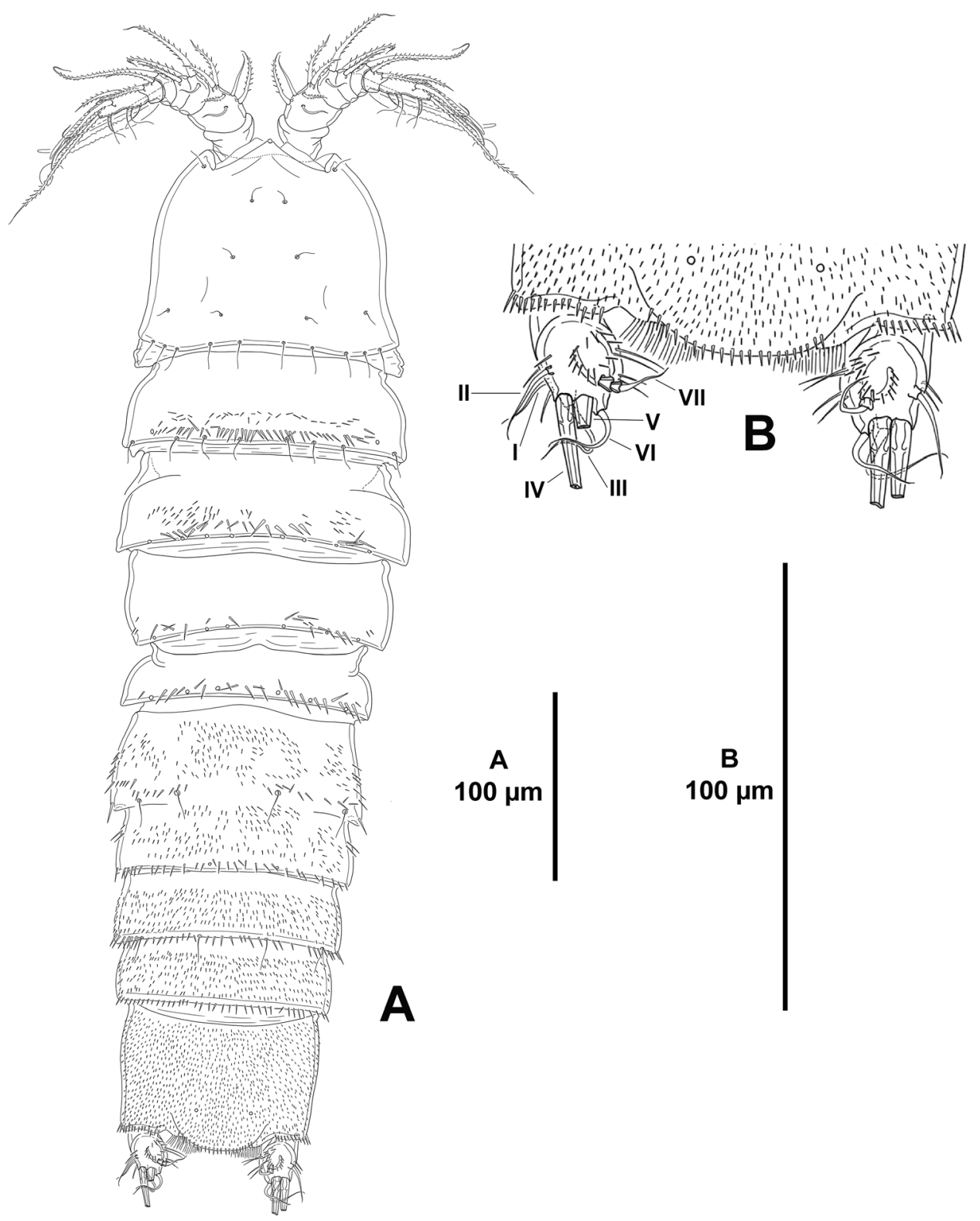

Figure 8. Odiliacletodes secundus sp. n., female holotype. A habitus, dorsal B posterior part of anal somite and caudal rami.

Description of female. Habitus (Figs 8A, 9A) cylindrical, without clear distinction between prosome and urosome. Total body length, $545 \mu \mathrm{m}$, measured from tip of rostrum to posterior margin of caudal rami.

Rostrum poorly-developed (Fig. 8A), fused to cephalothorax. I was unable to observe the two sensilla typically associated to the rostrum; the latter was probably fold- 


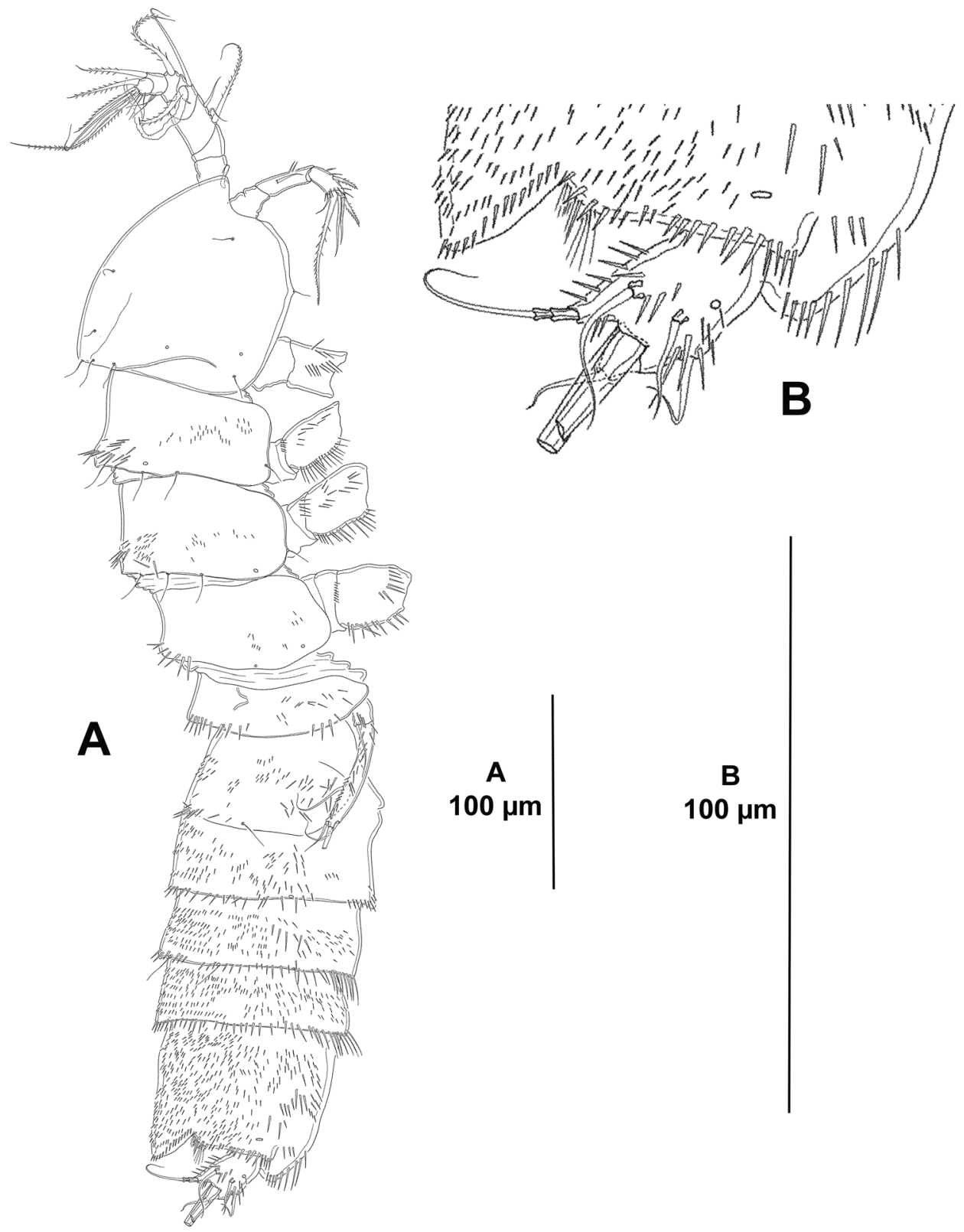

Figure 9. Odiliacletodes secundus sp. n., female holotype. A habitus, lateral B posterior part of anal somite and right caudal ramus.

ed downwards making the sensilla hard to see. The cephalothorax and free thoracic somites with smooth posterior margin (Figs 8A, 9A); with sensilla as shown, dorsal sensilla of P3-P4-bearing somites broken off in Fig. 8A; cephalothoracic integument with posterior rudimentary pleurotergite of fused P1-bearing somite. 
Urosomites with smooth posterior margin (Figs 8A, 9A). P5-bearing somite with spinules along posterior margin dorsally, with some spinules laterally. Second and third urosomites fused dorsally and ventrally forming genital-double somite (Figs $8 \mathrm{~A}, 10 \mathrm{~A}$ ), former division between both halves of genital-double somite indicated by dorsal transverse row of spinules close to posterior margin of anterior half (Fig. 8A) and by lateral chitinous rib (Fig. 9A); anterior half without spinules ventrally, posterior half with spinules along posterior margin dorsally and laterally (Figs 8A, 9A), ventrally with median spinular row flanked by two pores (Fig. 10A). Fourth and fifth urosomites (Figs 8A, 9A, 10A) covered with minute spinules dorsally, laterally and ventrally, with row of spinules close to posterior margin, of which, ventral spinules longer and stronger (Fig. 10A).

Anal somite as long as two preceding somites combined, square from dorsal and lateral view (Figs 8A, 9A), dorsal and lateral surface covered with minute spinules, ventral spinules less abundant and comparatively stronger (Fig. 10A), ventrally cleft medially, with spinules close to joint with caudal rami; anal operculum rounded, with
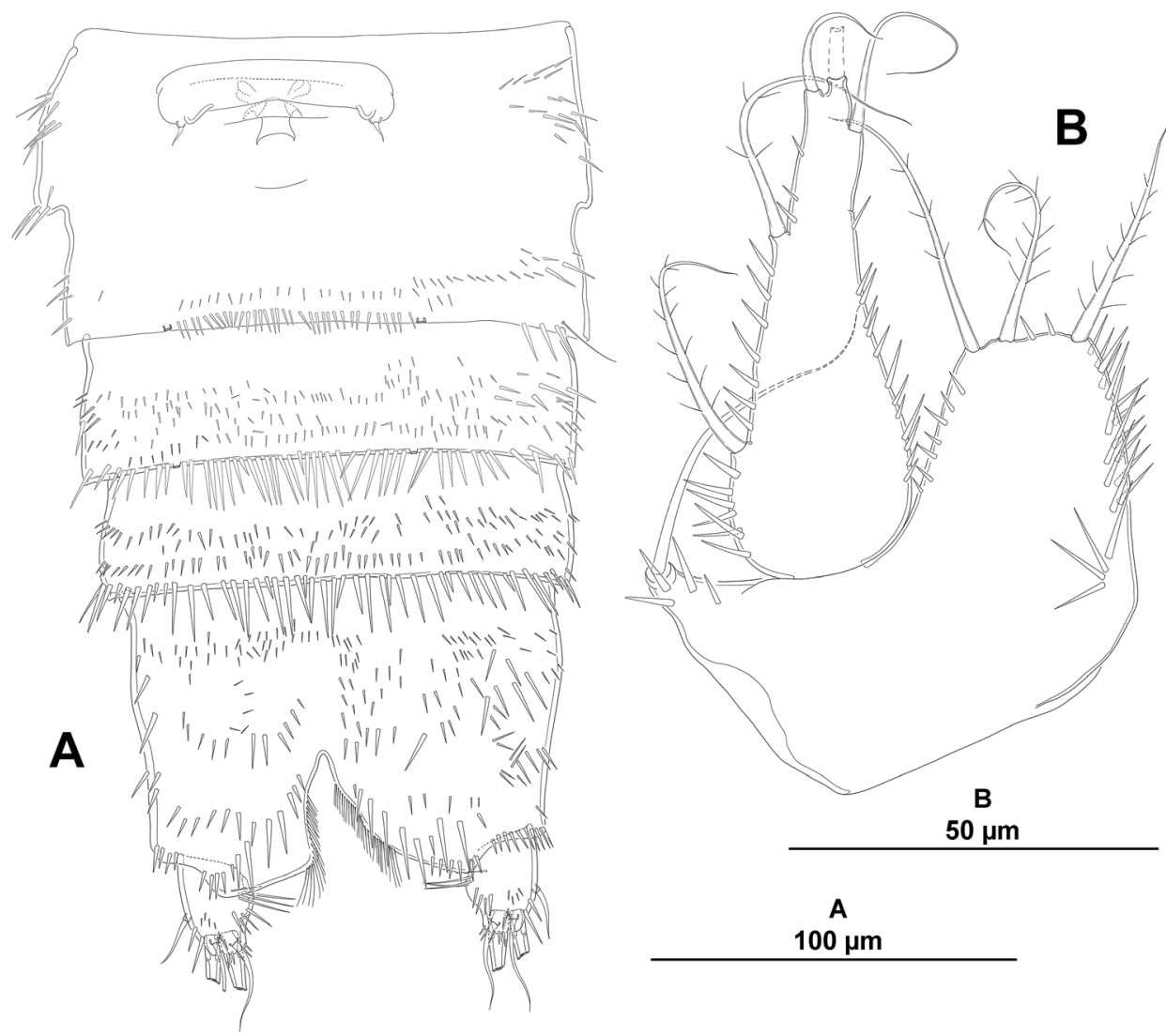

Figure 10. Odiliacletodes secundus sp. n., female holotype. A urosome, ventral (P5-bearing somite omitted) B P5, anterior. 
small spinules along posterior margin (Fig. 8A, B), associated surface ornamentation, two pores (seemingly without sensilla).

Caudal rami oval from dorsal (Fig. 8A, B) and ventral view (Fig. 10A), about 1.3 times as long as wide, rectangular from lateral view (Fig. 9B); with spinular ornamentation as shown; with seven setae as follows (Figs 8B, 9B): seta I ventral to seta II, aligned, subequal in length; seta III situated ventrally close to outer margin; setae IV and V longest; seta VI arising at inner distal corner; dorsal seta VII tri-articulated at base, issuing from median dorsal process.

Antennule (Fig. 11A). Hepta-segmented; surface of segments smooth except for two rows of spinules on first segment; second and last segments longest; sixth segment with two bipinnate elements and one slender, seemingly bare, short seta; last segment with eleven elements, five of which bi-articulated, three pinnate elements and acrothek, the latter consisting of one aesthetasc and two setae fused basally. Armature formula as follows: $1(0) ; 2(8) ; 3(3) ; 4(2+[1+\mathrm{ae}]) ; 5(1) ; 6(3) ; 7(8+[$ acro $])$.

Antenna (Fig. 11B). Allobasis with two sets of inner spinules as shown; without abexopodal seta. Exopod represented by single seta. Inner margin of free endopodal segment with longitudinal spinular rows; with two lateral inner spines subequal in length, and five distal elements (two spines, and two geniculate elements, of which outermost fused to one seta basally).

Mandible (Fig. 12A). Coxa without spinular ornamentation. Gnathobase with three serrated teeth and a single spine, and with a lateral seta. Palp bi-segmented; first

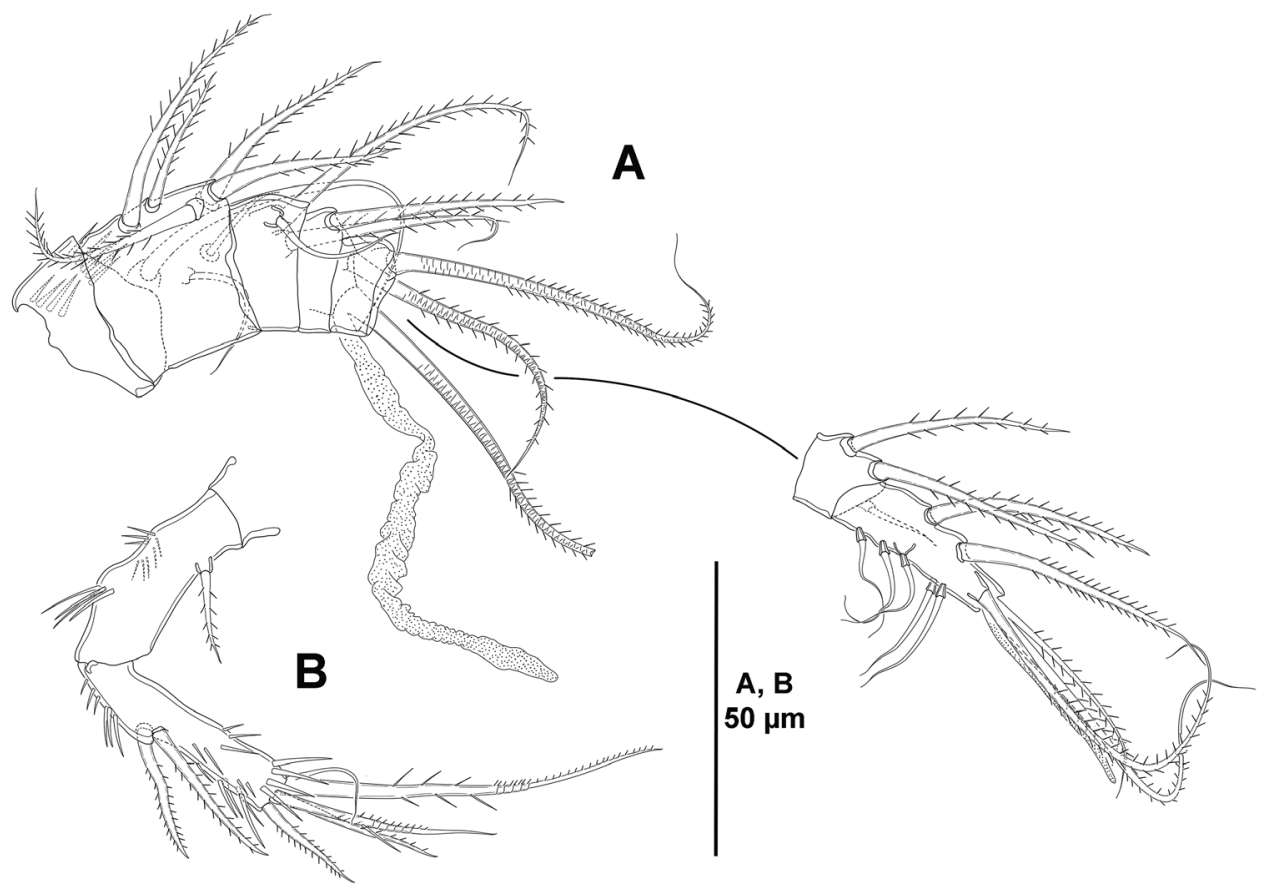

Figure I I. Odiliacletodes secundus sp. n., female holotype. A antennule B antenna. 
(basal) segment with few subdistal spinules, with two basal setae, with one outer (exopodal) seta; second (endopodal) segment without surface ornamentation, with one lateral seta, and two pairs of distal setae fused basally.

Maxillule (Fig. 12B). Arthrite of praecoxa armed with six apical spines, one lateral element, and two surface setae. Other parts lost during dissection.

Maxilla (Fig. 12C). Syncoxa with outer spinules, and with two endites; proximal endite small, with one slender seta; distal endite with two slender setae and one strong spinulose element. Allobasis without spinular ornamentation, drawn out into strong pinnate claw, with one slender bare seta and a strong spinulose spine. Endopod represented by two setae.

Maxilliped (Fig. 12D). Subchelate. Syncoxa with several rows of spinules as shown, with two setae. Basis with longitudinal outer spinules, unarmed. Endopod uni-segmented, fused to claw, the latter with subapical spinules.

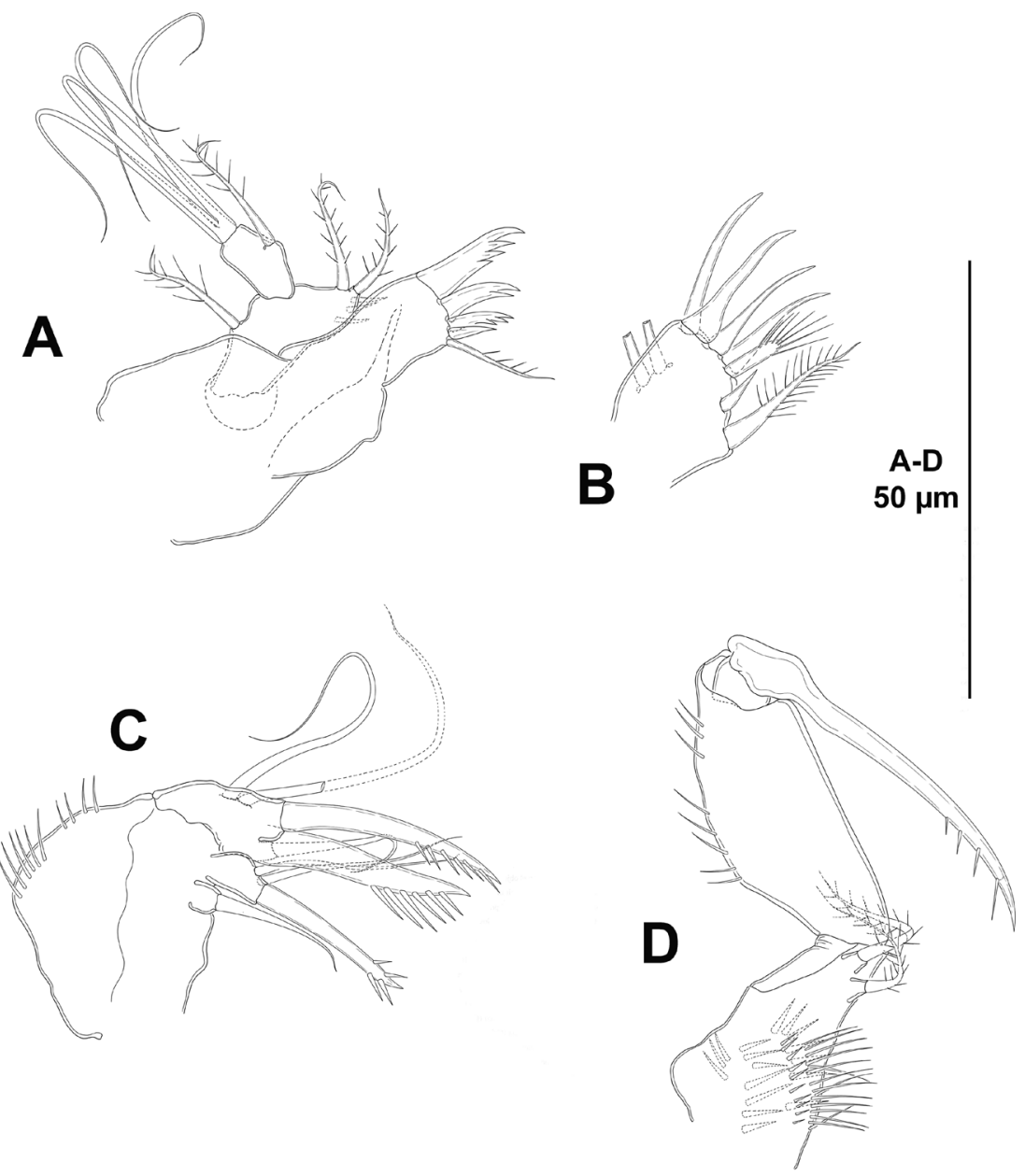

Figure 12. Odiliacletodes secundus sp. n., female holotype. A mandible B arthrite of praecoxa of the maxillule $\mathbf{C}$ maxilla $\mathbf{D}$ maxilliped. 
P1 (Fig. 13A). Coxa ornamented with spinules as shown. Basis with outer and inner seta, with spinules at base of outer and inner seta and between rami. Exopod and endopod subequal in length. Exopod tri-segmented; segments with outer and apical spinules as shown; first segment longest, second and third segments subequal in length; first segment without, second segment with one inner seta, third segment with two outer spines and two apical setae. Endopod bi-segmented; first segment about 1.3 times as long as wide, with outer and distal spinules on anterior face, and with some spinules on posterior face, with one inner seta; second segment elongate, 4 times as long as wide, and 1.7 times as long as first segment, with one inner element, two distal setae, and one outer spine.

P2-P4 (Figs 13B, 14A, B). Praecoxa with row of distal spinules. Coxa of P2 and P3 with one median row of spinules on anterior face, some spinules close to inner distal corner, and longitudinal row of spinules on anterior and posterior face, of $\mathrm{P} 4$ presumably as in P2 and P3. Basis with slender, long spinules along inner margin, with spinules between rami and at base of outer seta, the latter spine-like in P2, lost during dissection in P3 and P4. Exopod tri-segmented; first and third segment elongate, third segment slightly longer than first; second segment small; first segment with inner slender, and

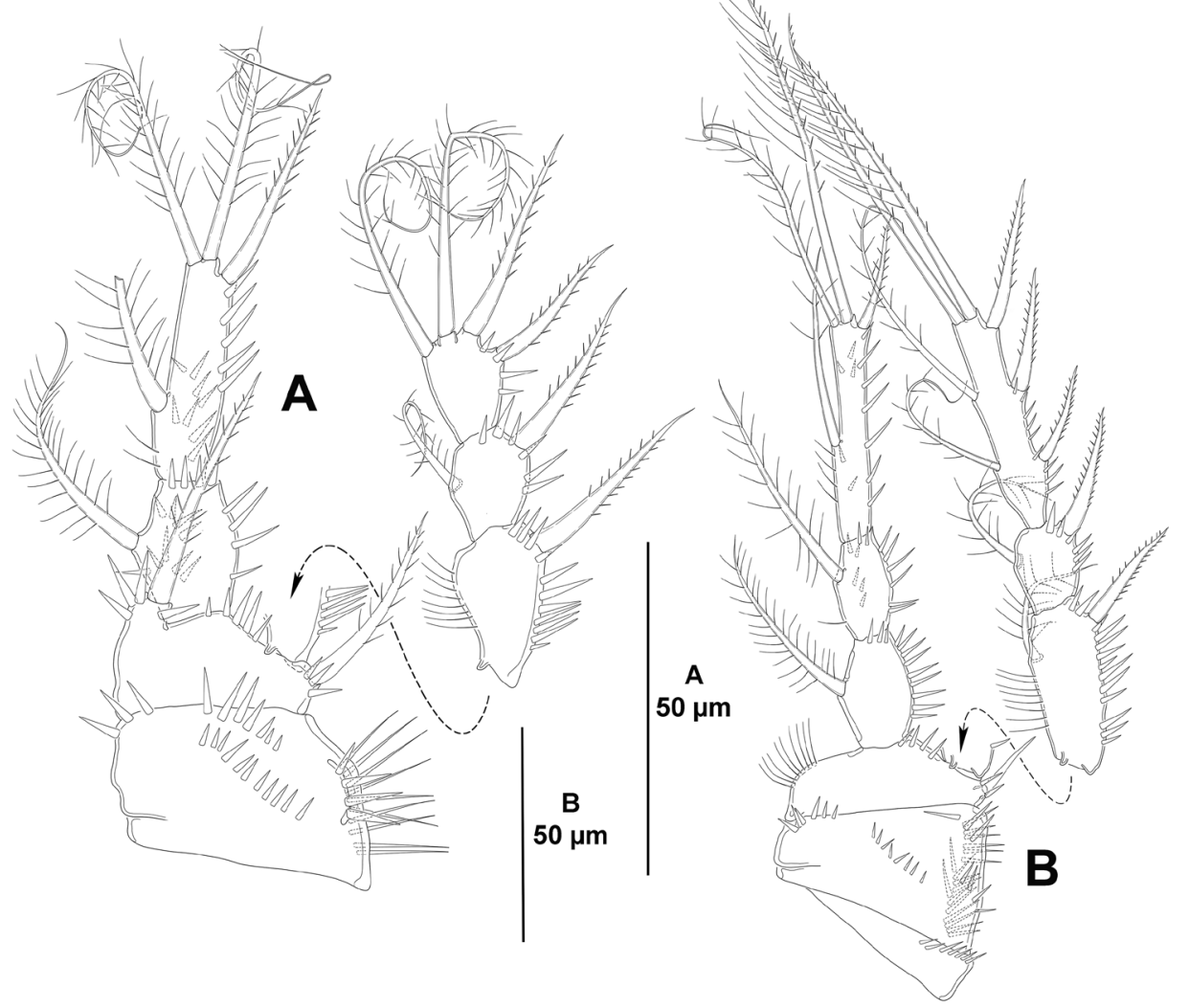

Figure 13. Odiliacletodes secundus sp. n., female holotype. A P1, anterior B P2, anterior. 


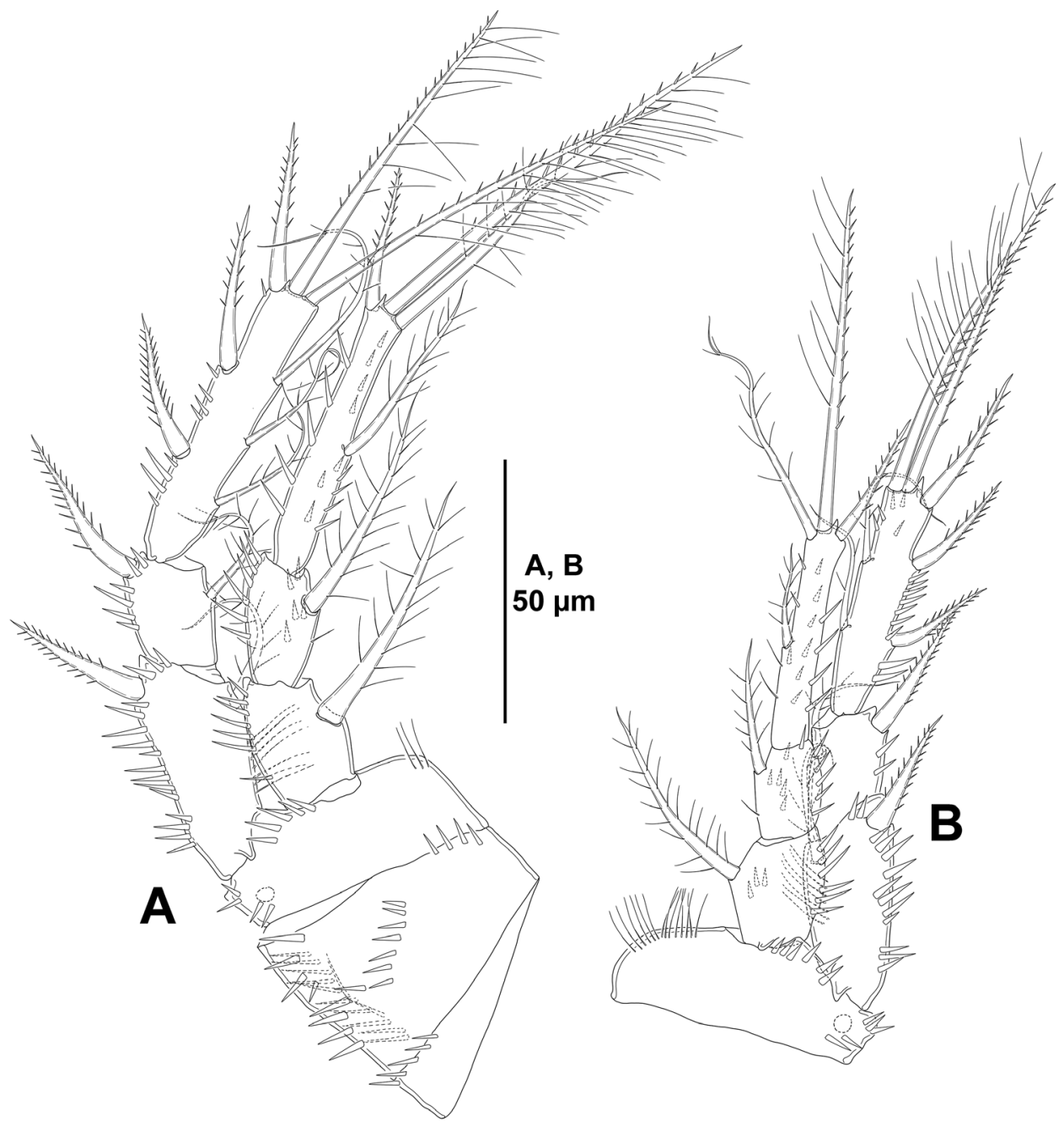

Figure 14. Odiliacletodes secundus sp. n., female holotype. A P3, anterior B P4, anterior.

outer strong spinules; second and third segments with outer spinules only; first and second segments with one inner seta; third segment of P2 and P4 with two inner setae, two apical elements, and three outer spines, of $\mathrm{P} 3$ with three inner elements, two apical elements, and three outer spines, outermost apical element on third exopodal segment of P2-P4 spine-like. Endopod tri-segmented; of P2 and P3 as long as exopod, of P4 reaching insertion of subdistal inner seta; first and second segments subequal in length; second segment elongate, longest, with one inner and two apical setae, and one outer spine.

Armature formula of $\mathrm{P} 1-\mathrm{P} 4$ as follows:

\begin{tabular}{c|c|c|c|c}
\hline & P1 & P2 & P3 & P4 \\
\hline EXP & $\mathrm{I}-0 ; \mathrm{I}-1 ; \mathrm{II}, 2,0$ & $\mathrm{I}-1 ; \mathrm{I}-1 ; \mathrm{III}, \mathrm{I} 1,2$ & $\mathrm{I}-1 ; \mathrm{I}-1 ; \mathrm{III}, \mathrm{I} 1,3$ & $\mathrm{I}-1 ; \mathrm{I}-1 ; \mathrm{III}, \mathrm{I} 1,2$ \\
\hline ENP & $0-1 ; \mathrm{I}, 2,1$ & $0-1 ; 0-1 ; \mathrm{I}, 2,1$ & $0-1 ; 0-1 ; \mathrm{I}, 2,1$ & $0-1 ; 0-1 ; \mathrm{I}, 2,1$ \\
\hline
\end{tabular}


P5 (Fig. 10B). Baseoendopod and exopod distinct. Baseoendopod with spinules at base of outer basal seta on short setophore, along inner and outer margin of endopodal lobe, and between innermost and adjacent endopodal seta; endopodal lobe reaching almost to middle of exopod, with three setae, of which outermost slightly longer, innermost and median seta subequal in length. Exopod elongated, triangular, 3 times as long as wide, with two outer, two apical and one inner seta, with inner and outer spinules as depicted, seemingly without tube-pores.

P6 (Fig. 10A) very reduced, each leg represented by one small seta; genital field situated proximally on first half of genital-double somite, with one aperture.

Male unknown.

Etymology. The specific epithet from the Latin secundus, second, refers to the second species of Odiliacletodes reported to date. The name is an adjective in the nominative singular, gender masculine.

\section{Discussion}

The family Argestidae, composed of 18 genera, is a typical deep-sea taxon (Hicks and Coull 1983, Huys and Conroy-Dalton 1997, George 2004) commonly found in muddy substrates, where it is one of the dominant harpacticoid taxa (Hicks and Coull 1983, George 2004, 2008, Menzel and George 2009, Menzel 2011a). Yet, some species of Argestes Sars, 1910, Argestigens Willey, 1935, Corallicletodes Soyer, 1966, Dizahavia Por, 1979, Eurycletodes, Fultonia Scott, 1902, Mesocletodes, and Parargestes Lang, 1944 have been reported from depths ranging from a few meters (e.g., $4.5 \mathrm{~m}$ for Dizahavia halophila Por, 1979, $35 \mathrm{~m}$ for Corallicletodes boutieri Soyer, 1966, $20 \mathrm{~m}$ for Eurycletodes (Oligocletodes) parasimilis, to less than $200 \mathrm{~m}$ (e.g., $91.44 \mathrm{~m}$ for Eurycletodes (O.) aculeatus (50 fathoms, not $50 \mathrm{~m}$ as in George (2004)), $150 \mathrm{~m}$ for Argestigens glacialis Lang, 1936, $180 \mathrm{~m}$ for Eurycletodes (O.) denticulatus, $60 \mathrm{~m}-120 \mathrm{~m}$ for Eurycletodes (Eurycletodes) laticauda) (for a complete list of depth range of the species of Argestidae and references see George (2004: 257-259, Table 2); for the genus Mesocletodes see Menzel et al. (2011)).

Despite George (2011: 157, fig. 18) gave a preliminary list of tentative apomorphies for Argestidae, at present, no true apomorphies have been detected to prove the monophyletic status of this family (George 2004, 2008, 2011). More recently, Corgosinho and Martínez Arbizu (2010) suggested that the shape and armature of the maxilla could shed some light on the monophyly of the family. Some advances towards the monophyly of the family have been presented earlier. Huys and Conroy-Dalton (1997) suggested that the genus Argestoides Huys \& Conroy-Dalton, 1997, currently relegated to incertae sedis within Argestidae, could eventually be accorded family rank occupying an intermediate position between the Ameiridae and Argestidae. George (2004) proved the monophyly of the genus Bodinia George, 2004, and relegated that genus as incertae sedis within Argestidae, and George (2008) proved the monophyly of the genus Argestes. Menzel and George (2009) showed the monophyly of Mesocletodes and of the Mesocletodes abyssicola-group, suggested that the loss of mouth parts in some 
species of Mesocletodes might support a monophylum of derived Argestidae, and that the presence of bifid dorsal processes on some other species might support another monophyletic clade within the M. abyssicola-group. George (2011) proved the monophyly of the genus Fultonia, created the subfamily Argestinae Por, 1986 for Fultonia and Argestes, and transferred the genus Parargestes into the latter genus (the latter action was previously suggested by George (2008)). Menzel (2011a) demonstrated the monophyly of the genus Eurycletodes, and of its two subgenera, E. (Eurycletodes) and $E$. (Oligocletodes), and allocated the enigmatic E. profundus Becker, 1979 into the subgenus E. (Oligocletodes).

The genus Eurycletodes, with 27 species, including the new species presented herein, is one of the most species-rich genera of Argestidae, outnumbered only by the genus Mesocletodes, and can account for up to $25 \%$ of total abundance of the entire family in sediment samples (Menzel 2011a). The position of Eurycletodes inside Argestidae is far from resolved, but Menzel (2011a) hypothesised that this genus could occupy a derived position within Argestidae given the loss of setae and fusion or loss of segments. For a complete account on the taxonomic history of the genus see Menzel (2011a). Briefly, Lang (1944) subdivided the genus Eurycletodes into two subgenera, E. (Eurycletodes), with Cletodes laticauda as its type species, and E. (Oligocletodes) Lang, 1944, with its type species C. lata T. Scott, 1892. The former was defined by the lack of inner armature on the P1 EXP2, and presence of three setae on the female P5 endopodal lobe. The latter was characterized by the presence of one inner seta on the P1 EXP2, but with two setae only on the female P5 endopodal lobe. In his monograph, Lang (1948) listed three species in the subgenus E.(Eurycletodes) (he was probably unaware of the description of $E$. (E.) gorbunovi), and ten species were recognized as members of E.(Oligocletodes). Subsequent description of 13 new taxa of Eurycletodes raised the number to 27 species within the genus. No new species attributable to the subgenus E. (Eurycletodes) have been described since Lang's (1948) monograph, 11 of 13 new species have been attributed to the subgenus E. (Oligocletodes), and two species, E. profundus and E. ephippiger, could not be attributed to any of these two subgenera (for example see Wells 2007).

Becker (1979) described E. profundus based on one female collected at $3820 \mathrm{~m}$ depth in Eastern Tagus Basin, off Portugal. Given the armature complement of the P1 EXP2 (with one inner seta) and P5 endopodal lobe (with only one seta) Becker (1979) suspected that his newly found species could well belong to a new subgenus of Eurycletodes. Later, to prove the monophyletic status of Eurycletodes, and to analyse the phylogenetic relationships within the genus, Menzel (2011a) gave three apomorphies [plesiomorphies] for Eurycletodes, viz. antennulary segments III and IV fused [antennulary segments III and IV separated], basal seta of the mandibular palp absent [basal seta of the mandibular palp present], and exopod of the mandibular palp reduced to one seta [exopod expressed]. Additionally, she considered the lack of inner armature of the P1 EXP2 as apomorphic for the subgenus E. (Eurycletodes) and did not accept Soyer's (1964) view regarding the apomorphic nature of the lack of inner armature of P4 EXP1 in E. (Oligocletodes) but considered this character potentially useful to characterize a monophylum within the genus. Also, she considered the presence of three 
setae on the endopodal lobe of the female P5 (outer, medial and inner seta) as plesiomorphic for Eurycletodes but considered the presence of two setae only (innermost seta lost) as apomorphic for $E$. (Oligocletodes). Under this scheme, she hypothesised further loss of the second terminal seta of the P5 endopodal lobe of E. profundus and attributed this species to $E$. (Oligocletodes).

Por (1964) described E. ephippiger based on three females from Rosh Hanikra (Israel, Mediterranean Sea) collected at $475.5 \mathrm{~m}$ depth. That same year, Soyer (1964) described E. knoepffleri Soyer, 1964 based on one female and one male from off BanyulsSur-Mer (Gulf of Lion, France, western Mediterranean) collected at $360 \mathrm{~m}$ and $390 \mathrm{~m}$ depth, respectively. Later, Bodin (1988), probably based on the strong similarities in the description of both species and on their presence in the Mediterranean, relegated $E$. knoepfleri as synonym of E. ephippiger. As noted by Menzel (2011a), neither E. ephippiger can be attributed to E. (Eurycletodes) nor E.(Oligocletodes) because of the presence of an inner seta on P1 EXP2 and three setae on the female P5 baseoendopod, both considered as plesiomorphic for Eurycletodes in Menzel (2011a), nor could it be placed at a basal position within the genus because no synapomorphies have been detected for the subgenera E.(Eurycletodes) and E. (Oligocletodes), to exclude E. ephippiger. The new species of Eurycletodes presented herein is undoubtedly related to the Mediterranean $E$. ephippiger. Based on Por's (1964) and Soyer's (1964) descriptions, both species can be separated by 1) the armature complement of the basis of the maxillule (basis with two setae, and exopod and endopod represented by one seta each in E. ephippiger, but with two basal and one exopodal seta in E. paraephippiger sp. n., 2) by the armature complement of the syncoxa of the maxilliped (with one seta only in the Mediterranean species, but with two setae in the new species), and 3) by the relative position of the anal operculum (situated in the middle of the anal somite in E. ephippiger, but posterior margin of anal operculum aligned with the anterior margin of caudal rami in the Mexican species. A more detailed re-description of E. ephippiger could shed some light on the position and relationships of the latter and the new species, within the genus Eurycletodes.

The genus Odiliacletodes is very rare and is known from a single female of its only species, O. gracilis, which was originally described from Banyuls-Sur-Mer (Gulf of Lion, France) at $610 \mathrm{~m}$ depth (Soyer 1964). More recently, Menzel and George (2012) reported on five adults and one copepodid attributable to O. gracilis and one adult of an undescribed species from the Eastern and Western Guinea Basin, and Northern Angola Basin (southeastern Atlantic), respectively, at 5000+ m depth. Soyer (1964) noted that $O$. gracilis could be related to the genus Fultonia given the bi-segmented endopod of P1 and the presence of up to four elements on the third endopodal segment of P2-P4. However, Odiliacletodes does not fit the diagnosis of the subfamily Argestinae by George (2011), to which the genus Fultonia belongs. As shown for O. secundus sp. n., the body surface of prosomites and first urosomite are not densely covered with small cuticular spinules (such surface ornamentation is present, to some extent on the genital-double somite and two succeeding somites, and only the anal somite is densely covered with small spinules), the sixth segment of the antennule possesses two bipinnate elements and one slender, seemingly naked, short seta, the latter homologous 
to the long, strong seta found on the same segment of the antennule of Fultonia and Argestes, and the dorsal thoracic sensilla are of "normal" (small) length.

Itô (1983) observed a "membranous structure...inserted beneath posterior hyaline membrane of cephalothorax and seemingly covering over articulation membrane between cephalothorax and first free thoracic somite" (Itô 1983: 238) in several deep-sea cerviniid and ameirid species. He, Itô (1983), interpreted this structure as a possible rudimentary pleurotergite of the fused first thoracic somite. George (2008) considered the presence of such pleurotergite in Argestes as another diagnostic character for that genus, and George (2011) as another synapomorphy uniting Argestes and Fultonia into the subfamily Argestinae. George (2011: 152) hypothesised that such pleurotergite could be regarded as a secondarily evolved joint to enhance the copepod's movement on or in the sediment, and that it could constitute another derived trait, but refrained to use that character in his phylogenetic analysis, since the nature of this structure is, at most, speculative. The presence of such pleurotergite in $O$. secundus sp. n. (its presence in $O$. gracilis still needs to be confirmed) indicates that it may have been evolved independently in several genera as an adaptation to life in or on the sediment.

Amongst the basal genera of Argestidae, Argestes, Dizahavia and Fultonia (see George 2008), only Fultonia (Argestinae; composed of four species) and Odiliacletodes (composed of two species), are known to bear a bi-segmented endopod of P1 and tri-segmented endopods of P2-P4. Argestes sarsi Smirnov, 1946 was described with a bi-segmented endopod of P1 and tri-segmented endopods of P2-P4. However, after a complex taxonomic history (see George 2011), A. sarsi has been relegated to species incertae sedis within Argestidae (Wells 2007, George 2011); this view has been adopted here. The position of Odiliacletodes within Argestidae remains unclear. However, Soyer's (1964) view regarding the relationship between Fultonia (and consequently, with Argestinae) and Odiliacletodes seems possible given the evidence above. However, at this point, this is, at most, speculative, and despite $O$. secundus sp. n. fitting the generic diagnosis by Soyer (1964), no clear synapomorphies have been detected for the genus. The redescription of $O$. gracilis could shed some light on these issues. Finally, as noted above, $O$. gracilis and $O$. secundus sp. n. are similar in almost every respect, but can be separated by 1) the armature complement of the syncoxa of the maxilliped (with one seta only in $O$. gracilis, but two in $O$. secundus sp. n.), 2) by the structure of the antenna (with basis and one segmented exopod in $O$. gracilis, but with allobasis and exopod represented by one seta only in $O$. secundus sp. n.), and 3) by the presence of one inner seta on P4 EXP3 in O. gracilis, but with two inner elements in O. secundus sp. $\mathrm{n}$. Intraspecific variability in deep-sea harpacticoids is greatly underestimated (George 2008, Menzel 2011b), but has been detected in the armature complement of P1 ENP and P2 ENP of Neoargestes variabilis Drzycimski, 1967 (Drzycimski 1967), and in P4 EXP3 of A. angolaensis (George 2008), and in the armature complement of P2-P4 ENP2 and surface ornamentation, among others, of M. elmari Menzel, 2011b (Menzel $2011 \mathrm{~b}$ ). Unfortunately, O. gracilis and $O$. secundus sp. n. are known from a single female each, and intraspecific variability of these two species could not be assessed. 


\section{Acknowledgements}

This study was financed by the Programa de Apoyo a Proyectos de Investigación e Innovación Tecnológica (PAPIIT) of the Dirección General de Asuntos del Personal Académico of the Universidad Nacional Autónoma de México (UNAM-DGAPAPAPIIT), project IN202116 Distribución y riqueza de comunidades de microinvertebrados poco conocidos del Golfo de California. This study is a contribution to project IN217306-3 Biocenosis de invertebrados bentónicos y pelágicos en aguas profundas del Pacífico Mexicano en relación con las condiciones ambientales. Ship time was provided by the Coordinación de la Investigación Científica, UNAM. The author thanks all scientists, students and crew members for their help and support during the Talud $\mathrm{X}$ cruise. I am grateful to two anonymous reviewers for their criticism and observations to improve the general content of this manuscript. Article processing charges were fully covered by the Instituto de Ciencias del Mar y Limnología of the Universidad Nacional Autónoma de México (ICML-UNAM).

\section{References}

Becker K-H (1979) Eidonomie und taxonomie abyssaler Harpacticoidea (Crustacea, Copepoda) Teil II. Paramesochridae, Cylindropsyllidae und Cletodidae. Meteor Forschungsergebnisse Reihe D - Biologie Supplement: 1-37.

Bodin P (1988) Catalogue des nouveaux copépodes harpacticoides marins. Université de Bretagne Occidentale, Brest, 288 pp.

Boeck A (1872) Nye Slaegter og Arter af Saltvands-Copepoder. Forhandlinger i VidenskabsSelskabet i Christiana 1872: 35-60.

Corgosinho PHC, Martínez Arbizu P (2010) Ameiridae Boeck and Argestidae Por revisited, with establishment of Parameiropsidae, a new family of Harpacticoida (Crustacea, Copepoda) from deep-sea sediments. Helgoland Marine Research 64: 223-255. https://doi. org/10.1007/s10152-009-0185-4

Drzycimski I (1967) Zwei neue Cletodidae (Copepoda Harpacticoida) aus dem Westnorwegischen Küstengebiet. Sarsia 29: 199-206. https://doi.org/10.1080/00364827.1967.10411081

George KH (2004) Description of two new species of Bodinia, a new genus incertae sedis in Argestidae Por, 1986 (Copepoda, Harpacticoida), with reflections on argestid colonization of the Great Meteor Seamount plateau. Organisms Diversity and Evolution 4: 241-264. https://doi.org/10.1016/j.ode.2004.02.003

George KH (2008) Argestes angolaensis sp. nov. (Copepoda: Harpacticoida: Argestidae) from the Angola Basin (Southeast Atlantic), and the phylogenetic characterization of the taxon Argestes Sars, including the redescription of A. mollis Sars, 1910, and A. reductus (Itô, 1983). Zootaxa 262: 223-262.

George KH (2011) Revision of the taxon Fultonia T. Scott (Copepoda: Harpacticoida: Argestidae), including the (re) description of some species, discontinuation of the genus $\mathrm{Pa}$ - 
rargestes Lang. Meiofauna Marina 19: 127-160. Available from: http://www.pfeil-verlag. de/04biol/pdf/mm19_11.pdf.

Gómez S (2018) A new record and a new species of the genus Rhizothrix (Copepoda: Harpacticoida: Rhizothrichidae) from the deep sea of the Gulf of California. Proceedings of the Biological Society of Washington 131: 7-18. https://doi.org/10.2988/17-00021

Gómez S (in press) New species of Argestidae Por, 1986 (Copepoda, Harpacticoida) from the deep Gulf of California. ZooKeys.

Gómez S, Conroy-Dalton S (2002) Description of Ancorabolus hendrickxi sp. nov. (Copepoda: Harpacticoida: Ancorabolidae) from the neotropics and notes on caudal ramus development within oligoarthran harpacticoids. Cahiers de Biologie Marine 43: 111-129.

Gómez S, Díaz K (2017) On some new species of Ancorabolidae Sars, 1909 from the Gulf of California: the genera Ceratonotus Sars, 1909, and Dendropsyllus Conroy-Dalton, 2003 (Crustacea, Copepoda, Harpacticoida). ZooKeys 657: 43-65. https://doi.org/10.3897/ zookeys.657.10725

Hicks GRF, Coull BC (1983) The ecology of marine meiobenthic harpacticoid copepods. Oceanography and Marine Biology Annual Review 21: 67-175.

Huys R, Boxshall GA (1991) Copepod evolution. The Ray Society, London, 468 pp.

Huys R, Conroy-Dalton S (1997) Discovery of hydrothermal vent Tantulocarida on a new genus of Argestidae (Copepoda: Harpacticoida). Cahiers de Biologie Marine 38: 235-249.

Itô T (1983) Harpacticoid copepods from the Pacific abyssal off Mindanao. II. Cerviniidae (cont.), Thalestridae, and Ameiridae. Publications of the Seto Marine Biological Laboratory 28: 151-254. https://doi.org/10.5134/176059

Lang K (1936) Die während der Schwedischen Expedition nach Spitzbergen 1898 und nach Grönland 1899 eingesammelten Harpacticiden. Kungliga Svenska Vetenskapsakademiens Handlingar 15: 1-55.

Lang K (1944) Monographie der Harpacticiden (vorläufige Mitteilung). Almqvist \& Wiksells Boktryckeri AB, Uppsala, 39 pp.

Lang K (1948) Monographie der Harpacticiden Vols. I \& II. Nordiska Bokhandeln, Stockholm, 1682 pp.

Menzel L (2011a) A new species of Eurycletodes Sars, 1909 (Copepoda: Harpacticoida: Argestidae) from the southern hemisphere including remarks on the phylogeny of the genus and its subgenera. Helgoland Marine Research 65: 479-493. https://doi.org/10.1007/s10152010-0237-9

Menzel L (2011b) First descriptions of copepodid stages, sexual dimorphism and intraspecific variability of Mesocletodes Sars, 1909 (Copepoda, Harpacticoida, Argestidae), including the description of a new species with broad abyssal distribution. Zookeys 96: 39-80. https:// doi.org/10.3897/zookeys.96.1496

Menzel L, George KH (2009) Description of four new species of Mesocletodes Sars, 1909 (Copepoda, Harpacticoida, Argestidae) and redescription of Mesocletodes robustus Por, 1965 from the South Atlantic, including remarks on the Mesocletodes abyssicola-group. Zootaxa 2096: 214-256.

Menzel L, George KH (2012) Copepodid and adult Argestidae Por, 1986 (Copepoda: Harpacticoida) in the southeastern Atlantic deep sea: diversity and community structure at the species level. Marine Biology 159: 1223-1238. https://doi.org/10.1007/s00227-012-1903-z 
Menzel L, George KH, Martínez Arbizu P (2011) Submarine ridges do not prevent large-scale dispersal of abyssal fauna: a case study of Mesocletodes (Crustacea, Copepoda, Harpacticoida). Deep-Sea Research I 58: 839-864. https://doi.org/10.1016/j.dsr.2011.05.008

Por FD (1959) Harpacticoide noi (Crustacea, Copepoda) din Mîlurile Mării Negre. Studii Si Cercetări de Biologie Seria Biologie Animalia 11: 347-368.

Por FD (1964) A study of the Levantine and Pontic Harpacticoida (Crustacea, Copepoda). Zoologische Verhandelingen 64: 1-128.

Por FD (1967) Level bottom Harpacticoida (Crustacea, Copepoda) from Elat (Red Sea), Part I. Israel Journal of Zoology 16: 101-165.

Por FD (1979) The Copepoda of Di Zahav pool (Gulf of Elat, Red Sea). Crustaceana 37: 13-30. https://doi.org/10.1163/156854079X00825

Por FD (1986) A re-evaluation of the family Cletodidae Sars, Lang (Copepoda, Harpacticoida). Syllogeus 58: 420-425.

Roe KM (1959) Some harpacticoids from Lough Ine, with descriptions of two new species. Proceedings of the Royal Irish Academy 60: 277-289.

Sars GO (1909) Copepoda Harpacticoida. Parts XXV \& XXVI Laophontidae (concluded), Cletodidae (part). An account of the Crustacea of Norway with short descriptions and figures of all the species. 5: 277-304.

Sars GO (1910) Copepoda Harpacticoida. Tachidiidae (concluded), Metidae, Balaenophilidae, supplement (part). An account of the Crustacea of Norway. With short descriptions and figures of all the species V: 337-368.

Sars GO (1920) Copepoda. Supplement. Parts VII \& VIII Harpacticoida (continued). An account of the Crustacea of Norway with short descriptions and figures of all the species. 7: 73-92.

Schriever G (1986) New Harpacticoida (Crustacea, Copepoda) from the North Atlantic Ocean. VIII. The description of Eurycletodes (Oligocletodes) quadrispinosa sp. n. and the male of E. (O.) monardi Smirnov (Cletodidae). Zoologica Scripta 15: 233-236. https:// doi.org/10.1111/j.1463-6409.1986.tb00225.x

Scott T (1892) Additions to the fauna of the Firth of Forth. Part IV. Annual Report of the Fishery Board for Scotland, Edinburgh 10: 244-272.

Scott T (1895) Additions to the fauna of the Firth of Forth. Part VII. Annual Report of the Fishery Board for Scotland, Edinburgh 13: 165-173.

Scott T (1902) Notes on gatherings of Crustacea collected by the fishery steamer "Garland", and the steam trawlers "Star of Peace" and "Star of Hope", of Aberdeen, during the year 1901. $20^{\text {th }}$ Annual Report of the Fishery Board for Scotland. Part III Scientific investigations.

Smirnov SS (1946) New species of Copepoda Harpacticoida from the Arctic Ocean. Trudy Dreifuyushchei Ekspeditsyai Glausemov Ledokol Por "Sedov" 3: 231-263.

Soyer J (1964) Copépodes harpacticoïdes de l'étage bathyal de la région de Banyuls-Sur-Mer. V.

Cletodidae T. Scott. Vie et Milieu 15: 573-643.

Soyer J (1966) Copépodes harpacticoides de Banyuls-Sur-Mer. III. Quelques formes du coralligéne. Vie Milieu, Sér. B. Oceanographie 17: 303-344.

Wells JBJ (2007) An annotated checklist and keys to the species of Copepoda Harpacticoida (Crustacea). Zootaxa 1568: 1-872.

Willey A (1935) Harpacticoid Copepoda from Bermuda. Part II. Annals and Magazine of Natural History, Ser. 10, 15: 50-100. https://doi.org/10.1080/00222933508654944 